\title{
Rockfish response to low-frequency ocean climate change as revealed by the diet of a marine bird over multiple time scales
}

\author{
Aileen K. Miller, William J. Sydeman* \\ Marine Ecology Division, PRBO Conservation Science, 4990 Shoreline Highway, Stinson Beach, California 94970, USA
}

\begin{abstract}
We examined the effects of ocean climate variability on juvenile rockfish Sebastes spp. from 1975-2002 in the central California Current by examining the diet of a local marine bird, the common murre Uria aalge, on multiple temporal scales. Responses to higher-frequency climate change (interannual El Niño and La Niña events) were strong, with declines in rockfish take in warmwater years. Responses to low-frequency climate events (e.g. shifts of the Pacific Decadal Oscillation, PDO) were less obvious. Inter-annual patterns showed no response to the 1976-1977 regime shift to warmer PDO conditions. Instead, rockfish use declined beginning in 1989, corresponding to another suggested regime change, then rebounded shortly after the hypothesized return to a cool phase of the PDO in the late 1990s. Intra-annual diet patterns, however, revealed changes in rockfish use well before 1989. These signals indicate that declines may have corresponded to the 1976-1977 regime shift but were lagged, possibly due to the long lifespan and intermittent recruitment of rockfish. This interpretation is supported by local upwelling patterns that show a lagged correlation between upwelling and juvenile rockfish abundance in the marine bird diet.
\end{abstract}

KEY WORDS: Climate change $\cdot$ Regime shift $\cdot$ PDO $\cdot$ Juvenile rockfish $\cdot$ Sebastes spp. $\cdot$ Common murre $\cdot$ Uria aalge $\cdot$ Intra-annual variability

\section{INTRODUCTION}

Changes in climate and ocean conditions create responses throughout marine communities (Aebischer et al. 1990, Hare \& Mantua 2000). Both upper- and lower-trophic level organisms are affected (Venrick et al. 1987, Beamish \& Bouillon 1993, Veit et al. 1996, Montevecchi \& Myers 1997, Mackas et al. 1998), though contrasting effects may be seen within a community (Anderson \& Piatt 1999). Biological responses to environmental changes have important ecological, and often economic, ramifications. Understanding the biological consequences of ocean climate variability is, therefore, of principal interest for both conservation and management.

As top-level predators, marine birds are affected by climate change through fluctuations in their prey resources. Temporal variability in predator-prey rela- tionships has proven valuable for demonstrating changes in stocks of forage fish and zooplankton that are difficult and expensive to monitor directly (e.g. Croxall et al. 1988, Hatch \& Sanger 1992, Montevecchi \& Myers 1996, Davoren \& Montevecchi 2003, Abraham \& Sydeman 2004). Since climate change will likely affect other organisms, in addition to the prey of top predators, shifts in predator-prey relationships can indicate broader changes in marine ecosystems.

Fluctuations in the prey resources of marine birds can be observed over multiple temporal scales. When evaluating the biological impacts of climate change, it is essential to understand the temporal scales at which responses will be seen. Depending on life history characteristics, prey may respond quickly to climate change, or their responses may be lagged, particularly if the effects are indirect or if the organisms are longlived (Francis et al. 1998). Furthermore, the overlap of 
low- and high-frequency climate variability may confound interpretation of marine organism responses to climate change.

To better understand how marine communities respond to climate change over multiple time scales, we examined the relationship between a pursuit diving seabird, the common murre Uria aalge, and one of its principal prey items in the central California Current, juvenile rockfish Sebastes spp. The California Current is an eastern boundary current system affected by basin-wide climate patterns. It is characterized by nutrient-rich upwelling and circulation transport that results in high, yet extremely variable, productivity (McGowan et al. 1998, 2003). Large-scale climate patterns have demonstrated impacts on local ocean conditions in the California Current that, in turn, create biological changes in this region. El Niño and La Niña events, warm and cool phases, respectively of the El Niño Southern Oscillation (ENSO; Trenberth 1997), occur every 3 to $7 \mathrm{yr}$ and are responsible for major fluctuations in ecosystem productivity in this region (Lenarz et al. 1995). On an inter-decadal scale, ecosystem productivity is affected by changes in the Pacific Decadal Oscillation (PDO; McGowan et al. 2003). The mechanisms driving inter-decadal changes are not well understood (Miller \& Schneider 2000); however, fluctuations in sea-surface temperature, sea-level pressure and other physical factors are widely used as indicators of PDO regimes (Mantua \& Hare 2002). Regime changes also may be viewed in terms of biological evidence as opposed to the physical evidence of the PDO. Hare \& Mantua (2000) found that some biological variables, primarily indices of fish stocks, showed evidence for an additional regime change in 1989. Of the variables that exhibited a response in 1989, most showed decreased productivity throughout the north Pacific; changes in the physical environment were not as apparent at this time.

Common murres provision their chicks with small forage fish and squid Loligo opalescens in the central California Current (Sydeman et al. 2001). In the past $30 \mathrm{yr}$, the majority of the diet was comprised of juvenile rockfish, primarily Sebastes jordani, and northern anchovies Engraulis mordax (Ainley \& Boekelheide 1990, Sydeman et al. 2001). Nestling diet provides an accurate index of local abundance of juvenile rockfish; from 1983-2002, the proportion of rockfish in the murre chick diet was highly correlated $\left(R^{2}=0.81\right)$ with juvenile rockfish population estimates based on midwater trawl surveys in the region (Sydeman et al. 1991, Ainley et al. 1993, Mills et al. in press). While trawl surveys provide a direct measure of rockfish abundance, using common murre diet as a measure is advantageous for this analysis as it provides a longer time series, beginning before the 1976-1977 regime change. Furthermore, the bird diet-based index provides an opportunity to examine higher frequency (within-season) changes in rockfish abundance. We can, therefore, compare patterns over multiple time scales. The annual proportion of rockfish in the chick diet, as in the trawl surveys, has varied among years and decades, but the response to inter-decadal climate change has been unclear. A major decrease in rockfish consumption by murres was shown after 1989-1990, but no shift was evident at the time of the 1976-1977 PDO regime change (Sydeman et al. 2001). The independent fish sampling began in 1983, so responses to the 1976-1977 event cannot be evaluated with that dataset. However, the trawl surveys do demonstrate the same declines in rockfish abundance that were seen in murre diet starting in 1989-1990 (S. Ralston, US National Marine Fisheries Service, pers. comm.).

Climate effects on fish abundance can be amplified by fishery impacts. Indeed, there have been fisheryrelated declines in adult populations of many commercial rockfish species in the central California Current (Ralston 1998). Fishery effects are probably not responsible for the major changes in rockfish consumption by common murres, however, since Sebastes jordani, the primary species taken, is not fished commercially (Lenarz 1992, Ralston et al. 2003).

Herein, we examine the response of rockfish to climate change by looking at patterns of common murre nestling diet over multiple time scales. Specifically, we examine intra-seasonal patterns of rockfish use and relate these patterns to the annual and decadal diet trends over $28 \mathrm{yr}, 1975-2002$. By bringing together patterns over multiple time scales, we are able to address (1) how juvenile rockfish abundance relates to inter-decadal climate patterns, (2) over which time scales these effects can be seen and (3) how local oceanographic variability may be related to rockfish abundance.

\section{MATERIALS AND METHODS}

Study site and climate conditions. Our research site, Southeast Farallon Island $\left(37^{\circ} 42^{\prime} \mathrm{N}, 123^{\circ} 00^{\prime} \mathrm{W}\right)$, is $42 \mathrm{~km}$ west of San Francisco, California, and about $5 \mathrm{~km}$ east of the continental shelf break (200 m isobath). Local and basin-scale climate conditions have varied widely during the study period. Several ENSO events had observed physical and biological effects in this area. Based on the Multivariate El Niño Index (www.cdc.noaa.gov), the strongest El Niño events (warm phases of ENSO) occurred during our study period in 1982-1983, 1986, 1991-1992 and 1997-1998. Less intense events occurred in 1976, 1980 and 1993-1995. La Niña events (cool phases of ENSO) 
occurred in 1975, 1988-1989 and 1999-2000. Common murre diet is affected not only by ENSO events that occur during the breeding season, but also by conditions in winter when rockfish parturition occurs (Love et al. 2002). When we refer to 'El Niño years' and 'La Niña years', we are indicating years when summer rockfish abundance could have been affected by recent ENSO events. Inter-decadal climate variability was also observed during the study period: the PDO was in a cool regime when the study began, then shifted to a warm regime in 1976-1977 (Trenberth 1990, Mantua \& Hare 2002). These warmer conditions persisted until 1998-1999 when conditions appear to have returned to a cool phase, at least in the California Current (Bograd et al. 2000, Durazo et al. 2001, Schwing et al. 2002, Peterson \& Schwing 2003).

Diet observations. Observations of common murre nestling diet were conducted for $30 \mathrm{yr}, 1973$ through 2002. We eliminated the first 2 yr of data, 1973-1974, because intra-annual data were insufficient for analyses. Adult murres carry single prey items (primarily forage fish) lengthwise in their bills. Prey items can be identified as adults arrive at the colony to feed nestlings. Observations were made from a blind $10 \mathrm{~m}$ above a study plot that ranged from about 90 to 150 breeding pairs over the study period. The plot is part of a large sub-colony that ranged from approximately 500 to 5000 breeding pairs (Sydeman 1999). The overall Farallon murre population varied from about 30000 to 110000 breeding birds over the study period, with peak numbers observed in 1982 (about 80000) and 2002 (about 110000) (Ainley \& Boekelheide 1990, PRBO unpubl. data).

Observations of provisioning were carried out during the peak of the chick-rearing period, lasting 30 to $40 \mathrm{~d}$ in most years. The calendar dates of observations have varied among years due to annual differences in the reproductive timing (Sydeman 1999). Changes in hatch date were considered, as timing of breeding may relate to rockfish availability. The long-term mean for hatch dates is 14 June $( \pm 8.74 \mathrm{~d})$; however, mean hatch dates have progressively become earlier shifting from 19 June in 1975 to 5 June in 2002. Hatching was delayed during severe El Niño events (as late as 13 July in 1983).

From 1975-1977, observations were conducted every 2 to 3 d over $14 \mathrm{~h}$ (06:00 to 20:00 h). From 1978-2002, diet was observed on most days for $2 \mathrm{~h} \mathrm{~d}^{-1}$, at rotating hours, and 3 'all day watches' (06:00-07:00 to 18:00-20:00 h) were conducted in most years.

Individual fish were identified to the lowest taxonomic level possible based on traits such as shape and color of tail, body and fins. Identifiable traits were determined by comparing observed prey items with samples collected during shipboard surveys and with samples of similar fishes collected from Rhinoceros
Auklets Cerorhinca monocerata on Southeast Farallon Island. Most prey items could be identified to genus; however, in the case of northern anchovies Engraulis mordax and Pacific sardines Sardinops sagax, identifications at this level were not always possible and so for this analysis they were grouped into the category 'anchovy/sardine'. The majority of prey items in this group were anchovies. Pacific sardines were not identified in the diet until 1992 and even in subsequent years, most of the 'anchovy/sardine' category was northern anchovy (97\% of those identified to species). Rockfish could not always be identified to species; however, the majority of rockfish observed were 0 ageclass shortbelly rockfish Sebastes jordani. Other species taken included 0 age-class yellow-tailed rockfish $S$. flavidus, 0 age-class blue rockfish $S$. mystinus and 1 age-class shortbelly rockfish. The composition of rockfish species taken over the 28 yr period may have varied, but due to the irregularity of species specific identification this variation cannot accurately be quantified.

Data treatment and statistical analyses. In order to justify using data collected at different times of day, we initially analyzed diet composition by time of day to investigate whether there was diurnal variability in diet composition. We used 3 'all day watches' from available years (1975-1977, 1990, 1993-1997 and 2001-2002) and summarized the proportion of rockfish in the diet by hour. Each year was analyzed separately. Because of potential serial autocorrelation in the within-day time series, we used the Cochrane-Orcutt regression procedure, a method which corrects for serially correlated residuals (Cochrane \& Orcutt 1949). As there was essentially no effect of time of day on the take of rockfish (see 'Results'), all dates and observation periods were used in further analyses regardless of the time of the observations.

We examined prey consumption, based on percent by number, intra-annually and inter-annually in order to compare patterns seen within seasons to those seen over years and decades. Sydeman et al. (2001) summarized annual diet composition of Southeast Farallon Island murres through 1997 based on total numbers of identified prey items ( $\mathrm{n}=164$ to 3975 items $\mathrm{yr}^{-1}$ ). We updated this dataset through 2002 and herein report these new results. Intra-annual variability in the use of juvenile rockfish was examined by summarizing the proportion of rockfish in the diet for each day. Only days with 10 or more observations were included in this summary. In 1992, all days had less than 10 observations, so analysis was omitted for this year, though we illustrate the data. To account for variability in overall phenology, we centered dates of observation to the mean hatch date for each year. In order to focus analysis on the peak of the chick-rearing season, we 
restricted observations to $10 \mathrm{~d}$ before through $30 \mathrm{~d}$ after the mean hatch date each year. Intra-annual variability in the use of rockfish is illustrated using locally weighted regression (LOWESS) smoothing functions. Linear and quadratic trends in the take of rockfish were tested using the Cochrane-Orcutt regression procedure. Regression coefficients were assumed to be significant if $\mathrm{p}<0.05$. All analyses were performed using STATA v. 7 (Stata Corporation 2002).

Oceanographic data. We examined several indices of ocean conditions near Southeast Farallon Island in a cursory attempt to examine how climate may be related to patterns of rockfish abundance. A previous analysis by Ainley et al. (1993) established a quadratic relationship $\left(\mathrm{R}^{2}=0.61\right)$ between the January/February upwelling index at $36^{\circ} \mathrm{N}$ and the proportion of rockfish in murre diet for 1973-1990. We reanalyzed this relationship using data from 1975-2002 (www.pfeg.noaa. gov:16080) in order to investigate if and how this relationship changed. We extended this analysis to include (1) sea surface temperature, taken daily from Southeast Farallon Island, (2) monthly upwelling index (www.pfeg.noaa.gov:160801) averaged from $36^{\circ} \mathrm{N}$ and $39^{\circ} \mathrm{N}$, and (3) number of days of 'intense' upwelling defined as the number of days with upwelling over $75 \mathrm{~m}^{3} \mathrm{~s}^{-1} 100 \mathrm{~m}^{-1}$ for January/February and over $200 \mathrm{~m}^{3} \mathrm{~s}^{-1} 100 \mathrm{~m}^{-1}$ for March/ April. These values represent the 90th percentile of daily upwelling index values during the respective month over the 28 yr (www.pfeg.noaa.gov:160801) of the study. All parameters were examined for 'winter' (January/February) and 'spring' (March/April), the times during which rockfish parturition and larval development typically occur (MacGregor 1986, Woodbury \& Ralston 1991). Initial examination of the data suggested there were lagged relationships between the number of days of intense upwelling in $1 \mathrm{yr}$ and the percentage of rockfish in subsequent years; we tested for lags by developing autocorrelation functions for the relationships between intense upwelling in year $x$ to rockfish in year $x$ to year $x+9$.

\section{RESULTS}

\section{Time of day effects on diet}

In general, time of day did not affect diet composition. Of 11 yr examined, significant variation occurred in only 2 yr. In 1976, the proportion of variance attributable to time of day was minimal $(\beta=-0.01, p=0.01$, $\left.\mathrm{R}^{2}=0.05\right)$, indicating wide variability in diurnal rockfish use. In 2002, more of the variance was explained by time of day $\left(\beta=-0.007, p=0.01, R^{2}=0.17\right)$. Since the effect of time of day was generally insignificant and/or weak, we included all days of observation in our analyses.

\section{Inter-annual diet trends}

Common murre nestling diet included forage fish as well as squid (Fig. 1, data through 1997 from Sydeman et al. 2001). Juvenile rockfish, northern anchovy and Pacific sardine comprised the majority of the diet; however, the relative dominance of these species varied widely among years. From 1975-1988, juvenile rockfish were the principal prey item in all years except El Niño years $(1976,1983,1986)$ and 1 anomalously warm-water year (1978). Juvenile rockfish use decreased in the early 1990s and almost disappeared from the diet by the late 1990s. Rockfish use increased greatly in 2001 and in 2002, rockfish were again a dominant prey item.

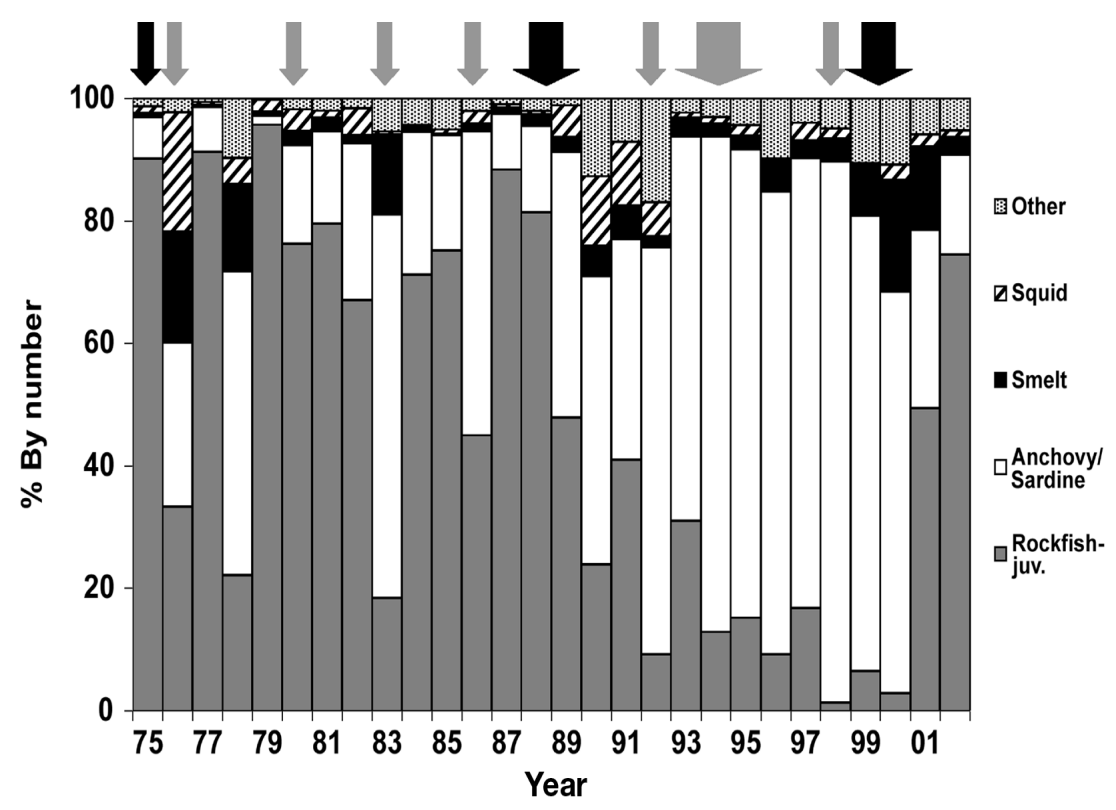

Fig. 1. Uria aalge. Inter-annual diet composition of common murre nestlings on Southeast Farallon Island, 1975-2002. Based on percent by number of juvenile rockfish Sebastes spp.; anchovy Engraulis mordax/sardine Sardinops sagax; smelt (Osmeridae); squid Loligo opalescens; and other diet items including Pacific butterfish Peprilus simillimus, juvenile salmon Oncorhynchus spp., flatfishes Bothidae and Pleuronectidae, juvenile lingcod Ophiodon elongatus, señorita Oxyjulis californica, and other species comprising less than $5 \%$ of the diet in any year. Years affected by El Niño events are indicated with gray arrows; those affected by La Niña years with black arrows 

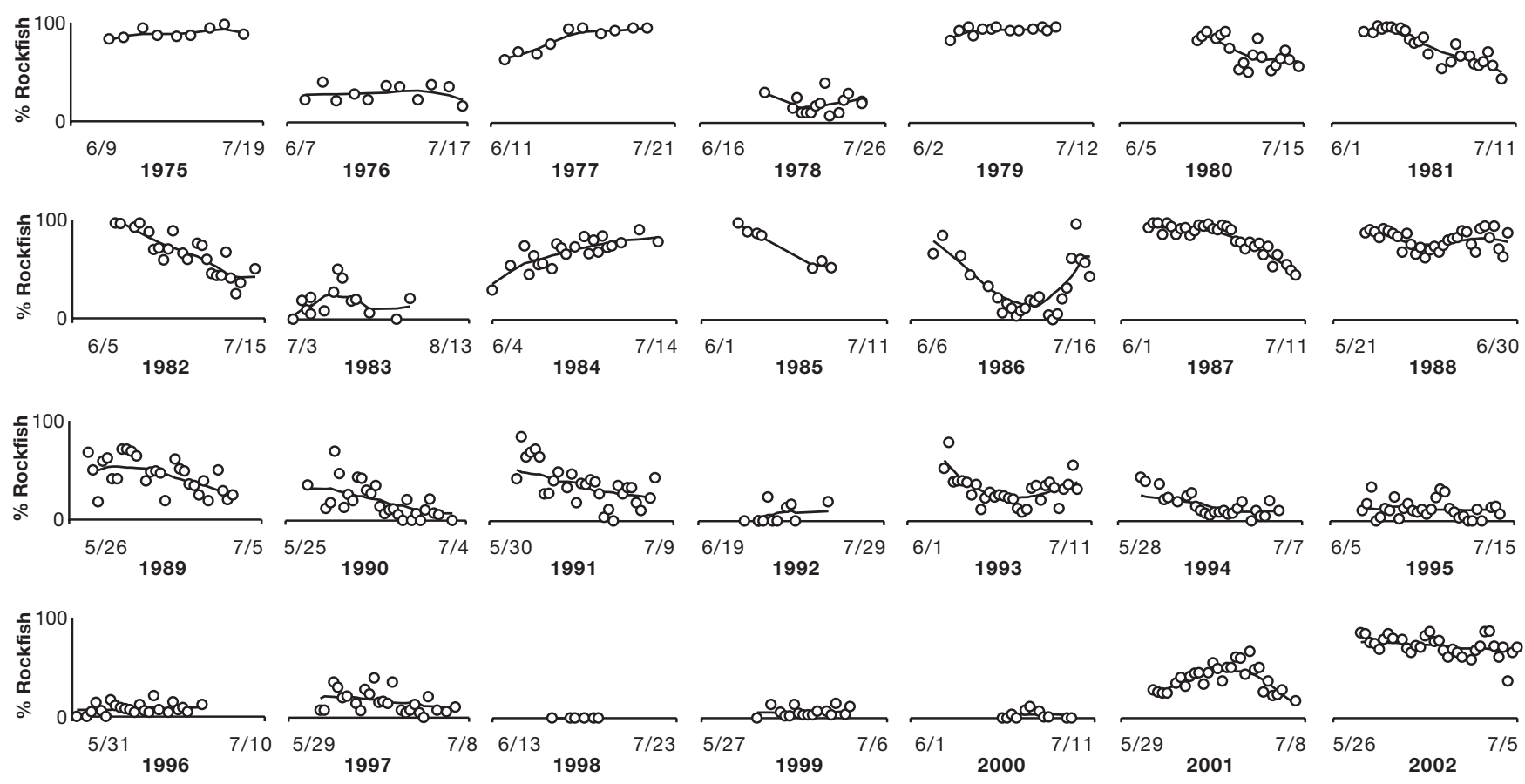

Fig. 2. Uria aalge and Sebastes spp. Intra-annual trends in amount of juvenile rockfish fed to common murre nestlings on Southeast Farallon Island, 1975-2002. Lines are locally weighted regression (LOWESS) smoothing curves. All observations fall within a window of $10 \mathrm{~d}$ before to $30 \mathrm{~d}$ after the mean hatch date. Dates given as mo/d

\section{Intra-annual diet trends}

Within-season variability in the use of rockfish was evident in many years; however, in some years early in the time series little variation was seen (Fig. 2). In general, take remained constant throughout seasons in the 1970s, while seasonal declines generally characterized the 1980s and early 1990s. In the mid to late 1990s, rockfish were nearly absent from the nestling diet throughout the seasons. Recent years suggest a return to the pattern of the 1970s.

Rockfish levels in the 1970s were typically high and remained constant throughout the season. In 1 El Niño year (1976), and 1 anomalously warm year (1978), the overall proportion of rockfish was lower, though the seasonal pattern was still constant (Fig. 2). From 1975 to 1979 , neither linear nor quadratic trends were significant in any year (Table 1).

In the $1980 \mathrm{~s}$, the proportion of rockfish in the diet began high then declined as the season progressed in most years. As overall take of rockfish fell during the late 1980s and early 1990s, seasonal declines were seen again, with several marked multi-year declines (Fig. 2). In 10 of 14 yr during the period 1980-1994, significant linear and/or quadratic declines were detected (Table 1). Of the $4 \mathrm{yr}$ that did not fit this pattern, 2 were El Niño years (1983 and 1986 when rockfish levels were low and erratic, 1 showed no trend (1988, a strong La Niña year) and 1 showed a seasonal increase in rockfish use (1984), an anomalous pattern in this 28 yr study. For several periods within the study, rockfish abundance at the beginning of the season corresponded to the rockfish abundance at the end of the season in the previous year. These patterns are seen most clearly in 1988-1990 and 1993-1995 (Fig. 2).

By the mid 1990s, rockfish use was consistently low in all seasons (Fig. 2), with little intra-annual variability. No significant trends were detected in 1995-2000, except in 1997, which showed a significant weak negative linear trend, and in 1999, when a slight quadratic trend was detected (Table 1). The trend in 1999, however, seems based on a few isolated days; in general, the levels of rockfish are close to zero on most days. In 2001, the first year rockfish began reappearing in murre diet, use increased during the first half of the season, then declined during the second half fitting a quadratic model. In 2002, rockfish levels were high and fairly constant, with no significant trend detected, similar to the pattern seen during the 1970s.

\section{Relationship to oceanographic variables}

Sea surface temperature and upwelling index averaged for $36^{\circ}$ and $39^{\circ} \mathrm{N}$ showed no relationships with the proportion of rockfish taken by common murres 
Table 1. Results of Cochrane-Orcutt regression analyses of intra-annual proportions of juvenile rockfish in common murre chick diet versus date. Significant linear models are indicated by an asterisk $\left({ }^{*}\right)$. Quadratic models are only shown if there is a significant quadratic trend

\begin{tabular}{|c|c|c|c|c|c|c|c|c|}
\hline Year & $\mathrm{R}^{2}$ & $\begin{array}{c}\text { Linear model: } \\
\beta\end{array}$ & $\mathrm{p}$ & $\mathrm{R}^{2}$ & $\beta_{1}$ & $\begin{array}{l}\text { Quadratic model: } \\
\text { p }\end{array}$ & $\beta_{2}$ & $\mathrm{p}$ \\
\hline 1975 & 0.25 & 0.0025 & 0.212 & & & & & \\
\hline 1976 & 0.00 & 0.0003 & 0.985 & & & & & \\
\hline 1977 & 0.32 & 0.0071 & 0.110 & & & & & \\
\hline 1978 & 0.07 & 0.0049 & 0.346 & & & & & \\
\hline 1979 & 0.19 & 0.0014 & 0.160 & & & & & \\
\hline 1980 & 0.26 & -0.0163 & $0.030^{*}$ & & & & & \\
\hline 1981 & 0.69 & -0.0180 & $>0.001^{*}$ & & & & & \\
\hline 1982 & 0.62 & -0.0213 & $>0.001^{*}$ & & & & & \\
\hline 1983 & 0.01 & -0.0030 & 0.721 & & & & & \\
\hline 1984 & 0.70 & 0.0109 & $>0.001^{*}$ & & & & & \\
\hline 1985 & 0.98 & -0.0221 & $>0.001^{*}$ & & & Insufficient data & & \\
\hline 1986 & 0.00 & 0.0060 & 0.779 & 0.45 & -0.0018 & 0.792 & 0.0029 & 0.001 \\
\hline 1987 & 0.48 & -0.0170 & $>0.001^{*}$ & 0.88 & -0.0140 & $>0.001$ & -0.0008 & $>0.001$ \\
\hline 1988 & 0.00 & -0.0002 & 0.937 & & & & & \\
\hline 1989 & 0.23 & -0.0092 & $0.012^{*}$ & & & & & \\
\hline 1990 & 0.31 & -0.0141 & $0.003^{*}$ & & & & & \\
\hline 1991 & 0.30 & -0.0160 & $0.003^{*}$ & 0.57 & -0.0173 & $>0.001$ & 0.0014 & 0.003 \\
\hline 1992 & & Insufficient data & & & & & & \\
\hline 1993 & 0.00 & -0.0017 & 0.740 & 0.56 & -0.0044 & 0.044 & 0.0015 & $>0.001$ \\
\hline 1994 & 0.19 & -0.0072 & $0.035^{*}$ & 0.71 & -0.0087 & $>0.001$ & 0.0008 & 0.001 \\
\hline 1995 & 0.04 & -0.0027 & 0.313 & & & & & \\
\hline 1996 & 0.05 & 0.0014 & 0.298 & & & & & \\
\hline 1997 & 0.23 & -0.0071 & $0.018^{*}$ & & & & & \\
\hline 1998 & & No rockfish & & & & & & \\
\hline 1999 & 0.02 & 0.0008 & 0.636 & 0.31 & 0.0006 & 0.678 & 0.0006 & 0.045 \\
\hline 2000 & 0.07 & -0.0036 & 0.455 & & & & & \\
\hline 2001 & 0.03 & -0.0059 & 0.414 & 0.57 & 0.0016 & 0.477 & -0.0016 & 0.000 \\
\hline 2002 & 0.09 & -0.0041 & 0.096 & & & & & \\
\hline
\end{tabular}

during the 1975-2002 study period ( $\mathrm{p}>0.05)$. We also found no relationship between January/February upwelling index at $36^{\circ} \mathrm{N}$ and rockfish abundance in murre diet for all years $\left(\beta_{1}=0.004, \mathrm{p}_{1}=0.18, \beta_{2}=\right.$

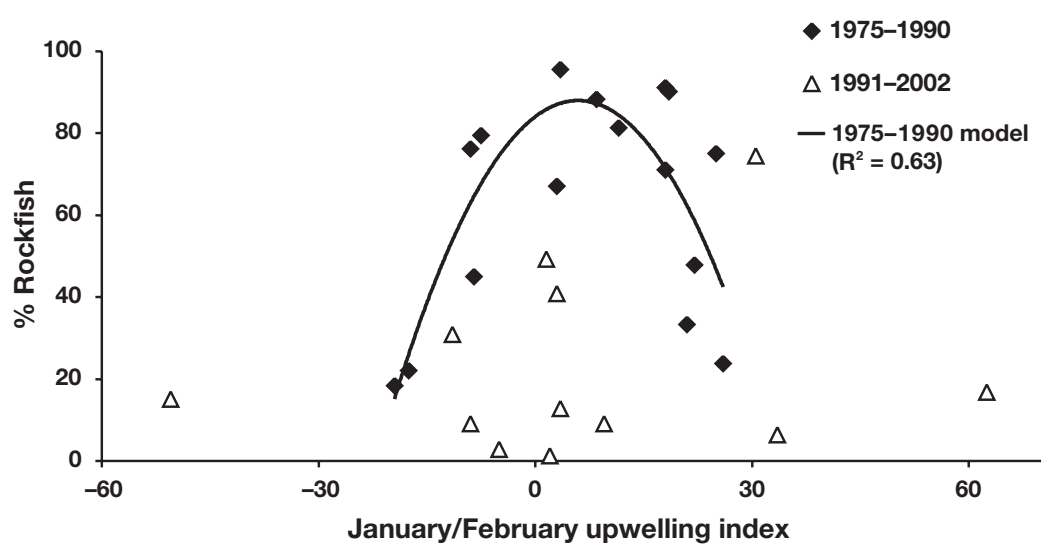

Fig. 3. Uria aalge and Sebastes spp. Percentage of rockfish in common murre nestling diet in relation to January/February upwelling index at $36^{\circ} \mathrm{N}, 1975-2002$. Quadratic line indicates relationship established by Ainley et al. (1993) for 1975-1990 that does not fit the relationship in subsequent years
$-0.0001, \mathrm{p}_{2}=0.10, \mathrm{R}^{2}=0.13$ ). Years during the $1990 \mathrm{~s}$ did not fit the quadratic relationship established by Ainley et al. (1993) for 1975-1990 (Fig. 3). Nonetheless, upwelling still appeared to influence inter-annual rockfish abundance: use of rockfish increased when the frequency of intense upwelling events in January/February increased and decreased when the frequency of intense upwelling decreased (Fig. 4a). The magnitude of increases and decreases were not the same, however.

In the spring (March/April), lagged relationships could be seen between the frequency of intense upwelling and the proportion of rockfish in the diet (Fig. 4b). The frequency of intense upwelling in this time period decreased beginning in the early 1980s. Following this change, the proportion of rockfish in common murre diet decreased in the late 1980s. The frequency of intense upwelling increased again in 1997, then rockfish returned as a major component of murre diet in 2001-2002. There were significant relationships between intense upwelling and rockfish 


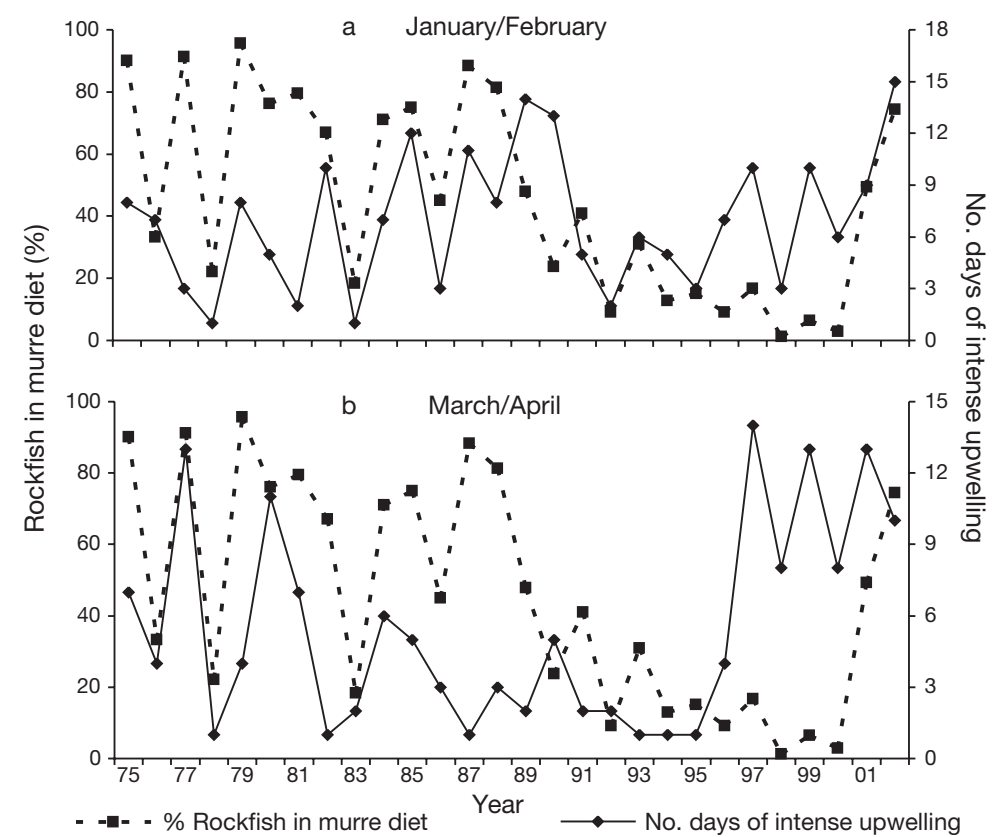

Fig. 4. Uria aalge and Sebastes spp. Number of days of intense upwelling (90th percentile of all daily values for the respective month) for (a) January/February and (b) March/April, and the proportion of rockfish in common murre nestling diet, 1975-2002

in the diet at lags of $4 \mathrm{yr}\left(\beta=0.0405, \mathrm{p}=0.01, \mathrm{R}^{2}=0.24\right)$, $5 \mathrm{yr}\left(\beta=0.0418, \mathrm{p}=0.01, \mathrm{R}^{2}=0.29\right)$ and $7 \mathrm{yr}(\beta=0.0429$, $\left.\mathrm{p}=0.02, \mathrm{R}^{2}=0.25\right)$. The $7 \mathrm{yr}$ lag appears to reflect the decrease in rockfish abundance following a decrease in the frequency of intense spring upwelling events in the earlier half of the study period, while the 4 and $5 \mathrm{yr}$ lags appear to reflect the increase in rockfish following an increase in upwelling in the later half of the study.

\section{DISCUSSION}

Patterns of juvenile rockfish use in common murre nestling diet changed notably over decades. On an inter-annual time scale, rockfish use began high, decreased dramatically after 1989 (Sydeman et al. 2001), then rebounded beginning in 2001. Seasonal trends, however, show that rockfish use was changing well before 1989. At the beginning of the study, the PDO was in a cool phase and the proportion of rockfish in the diet was often high and did not change within seasons. In the 1980s, after the 1976-1977 shift to a warm phase of the PDO (Mantua \& Hare 2002), the proportion of rockfish often declined during each season. Seasonal declines continued to be observed, including several periods of notable multi-year declines, until the mid to late 1990s when the overall proportion of rockfish was extremely low and remained so within and among seasons. In 2001 and 2002, a few years after the hypothesized return to a cool regime (Schwing et al. 2002, Peterson \& Schwing 2003), rockfish returned as a dominant prey item with a seasonal pattern in 2002 similar to those of the 1970s during the last cool regime. Shortbelly rockfish Sebastes jordani, the most common species taken by murres, are not fished commercially (Ralston et al. 2003). The close parallels between rockfish take by the birds, El Niño and La Niña events, and changes in inter-decadal climate patterns including the PDO make climate a compelling explanation for the intra-annual and inter-annual variability we observed.

Significant effects of inter-decadal climate variability have been documented in numerous fish populations, particularly in salmon, which show a strong association between their productivity and climate regimes (Francis \& Hare 1994, Hare \& Francis 1995, Mantua et al. 1997, Beamish et al. 1999). Regime effects have also been documented for groundfish species, particularly with effects on recruitment (McFarlane \& Beamish 1992, Hollowed et al. 1998, Clark et al. 1999). Rockfish in the central California Current may also be affected by climate change, both directly and indirectly. Direct effects may include habitat displacement, primarily during the larval stages when individuals may be advected offshore in association with intense upwelling (Larson et al. 1994). We demonstrate, however, that the frequency of intense upwelling events decreased during the time of rockfish declines (Fig. 4), suggesting that habitat displacement may not have been an important factor in rockfish population trends. An indirect effect of climate change on rockfish could be changes in their prey base that could affect adult fecundity or timing of parturition, or survival during larval or juvenile stages.

The intra-annual rockfish declines seen in the 1980s and early 1990s may correspond to the settlement of juvenile rockfish during the chick-rearing period. Young of the year rockfish remain in the epipelagic zone, in mid-water schools, until June or July when they settle and recruit to demersal habitats (Love et al. 2002). We would not expect to see this settlement in the late 1990s because the amount of rockfish in the diet was already very low. What is surprising is that this pattern is not seen in the 1970 s, when the overall proportion of rockfish was comparable to the 1980s.

Why were common murres consuming more juvenile rockfish late in the season in the 1970s during the cool regime? Francis et al. (1998) outlined 3 key aspects of a marine bird's prey base that can be affected by climate change: (1) prey availability, (2) prey abundance and (3) the mix of prey species available. Prey availability 
depends on a temporal and spatial match between predator and prey; that is, rockfish must be in the right place at the right time in order for murres to catch them. If rockfish parturition dates better matched the murre chick-rearing period before the 1976-1977 regime shift, then late season availability of juvenile rockfish would have been greater. The chick-rearing period was later on average in the 1970s, meaning that rockfish parturition dates must have also been later in order to support this match/mismatch hypothesis. Given that rockfish parturition is typically earlier during years of cooler oceanographic conditions (Woodbury \& Ralston 1991), this seems unlikely. Rockfish parturition dates could also have been more variable in the 1970 s, providing more juvenile rockfish late in the season; however, if the only affect of the regime change was a seasonal mismatch of common murre breeding dates and rockfish availability, we might expect a more immediate and defined response. In fact, the change in seasonal patterns was subtle and gradual.

Prey abundance provides a more compelling explanation for seasonal patterns of rockfish use. Better reproductive conditions for rockfish during the cool regime may have led to higher numbers of pelagic juveniles. A larger population of juveniles during the 1970s would mean that even late in the season there could have been enough rockfish to dominate common murre diet. In contrast, as juvenile populations decreased, late season declines in rockfish use would have become apparent. Chronically diminished juvenile populations should eventually affect adult population size, particularly since year class strength is largely determined by the pelagic juvenile stage in some rockfish species (Ralston \& Howard 1995).

The evidence we present here of seasonal changes in common murre diet suggests that rockfish populations were gradually affected over the 20 yr following the shift from a cool to a warm regime. Sebastes jordani generally live at least $30 \mathrm{yr}$, reaching maturity at 2 to 5 yr (Love et al. 2002). This long life span may have led to a delayed effect on population size. Rockfish populations are highly dependent on year class strength (Ralston \& Howard 1995), and a prolonged period of sub-optimal reproductive conditions following the regime change may have prevented strong year classes from developing, ultimately leading to a significant reduction in population size. Indeed, annual rockfish abundance in the murre diet shows correlation with spring upwelling, though it is lagged (Fig. 4). Rockfish take decreased around 7 yr after the frequency of intense spring upwelling decreased, then increased 4 to $5 \mathrm{yr}$ after spring upwelling increased. The correlations between frequency of intense upwelling and rockfish abundance 4, 5 and
7 yr later are significant. Lagged responses to regime change have been shown in other groundfish due to the long life span and intermittent recruitment success of many of these species (Anderson \& Piatt 1999, Clark et al. 1999).

Functional relationships between ocean climate and marine organisms are difficult to establish, particularly when relationships are lagged, as appears to be the case with rockfish in the central California Current. Further confounding the situation, we found that a relationship between juvenile rockfish population patterns and ocean climate which held for 16 yr has now changed: upwelling in January and February was an important factor in determining annual rockfish use in murre diet for 1975-1990, but in more recent years (1991-2002), January and February upwelling did not explain these patterns. This change indicates that some other system-wide shift may have been important in determining juvenile rockfish abundance in recent years; it may also be a signal of a decline in adult rockfish abundance or fecundity in the California Current. Upwelling may have been a useful indicator for juvenile production if the adult population was stable, but could lose its predictive power if there was a decline in adult rockfish fecundity or population size.

Using the diets of marine birds as a tool for monitoring fish populations comes with limitations since it is an indirect measure, though it also provides some notable benefits (Cairns 1987, Montevecchi 1993). A limitation in our interpretation follows the third effect of climate change addressed by Francis et al. (1998): patterns of rockfish use may be affected by the availability of alternate prey species. Changes in abundance of different rockfish species could not be reliably assessed in common murre diet but may have affected the patterns we describe. Further, the other major prey item taken by murres on Southeast Farallon Island, northern anchovy, could have been more or less available in certain years or at certain times within a season. Without a local assessment of anchovies and other prey resources, we cannot discount their influence on the patterns we reported; however, several factors point to rockfish as a 'preferred' prey item. First, annual proportions of rockfish in common murre nestling diet are strongly correlated with net samples of rockfish recruitment in the region, indicating that when rockfish are available, common murres prey upon them before exploiting other species (Mills et al. in press). Second, foraging trip duration is reduced when feeding on rockfish because, in general, pelagic juveniles are found in closer proximity to the breeding colony on Southeast Farallon Island (Ainley \& Boekelheide 1990). At-sea surveys of common murres show that when the diet changed from rockfish to anchovies in the late 1980s and early 1990s, murre foraging habi- 
tat shifted towards the coast (Oedecoven et al. 2001). As the diet changed back to rockfish in the early 2000s, their habitat shifted back offshore, closer to the breeding colony (Yen et al. 2004). Analysis of stomach contents of adult common murres also demonstrated that those feeding on the coast generally prey upon anchovies, while those closer to the breeding colony prey mainly upon rockfish (Ainley et al. 1996). Thus, we are confident that patterns in the murre diet are more reflective of environmental variability acting on rockfish availability and abundance than of murres switching to alternate prey resources.

The primary benefit we gain from monitoring fish population dynamics through studies of marine bird diet, in this case, is a time series and a level of detail that is unlikely to be found in any direct monitoring of these fish populations. We present daily data for a 30 to $40 \mathrm{~d}$ period over $28 \mathrm{yr}$. Without this level of detail, the effects of the regime changes on rockfish populations would have been obscured. When data were summarized on only an annual time scale, no changes were observed at the time of the 1976-1977 regime shift or even in the decade following. When we looked at seasonal as well as annual diet patterns, however, the influence of inter-decadal climate regimes on rockfish was revealed. The relevance of short-term observations in interpreting the effects of long-term patterns in this study is surprising and indicates the importance of considering multiple time scales when assessing biological responses to climate change. This study also points to the value of using marine birds as indicators of the status of local ecosystems and food webs. By using common murres as a sampling tool, we were able to gather the intra-annual records necessary to demonstrate the effects of inter-decadal climate patterns on rockfish abundance.

Acknowledgements. We gratefully acknowledge the hard work and dedication of the many Farallon biologists and field research assistants who made this long-term study possible, as well as D. G. Ainley and R. J. Boekelheide, who initiated the project in the 1970s. Field work was supported, in part, by the San Francisco Bay National Wildlife Refuge/US Fish and Wildlife Service under cooperative agreement. Other financial support was provided by the Bradford Foundation, the Homeland Foundation, and PRBO - Friends of the Farallones. Write-up was sponsored by the Packard Foundation. This manuscript has benefited from reviews by I. Perry, A. MacCall, W. A. Montevecchi, R. W. Bradley, K. L. Mills and 3 anonymous reviewers. To all we offer sincere gratitude. This is PRBO contribution no. 1129.

\section{LITERATURE CITED}

Abraham CL, Sydeman WJ (2004) Ocean climate, euphausiids, and auklet nesting: inter-annual trends and variation in phenology, diet and growth of a planktivorous seabird, Ptychorampus aleuticus. Mar Ecol Prog Ser 274:235-250
Aebischer NJ, Coulson JC, Colebrook JM (1990) Parallel long-term trends across 4 marine trophic levels and weather. Nature 347:753-755

Ainley DG, Boekelheide RJ (eds) (1990) Seabirds of the Farallon Islands. Stanford University Press, Palo Alto, CA

Ainley DG, Sydeman WJ, Parrish RH, Lenarz WH (1993) Oceanic factors influencing distribution of young rockfish (Sebastes) in central California: a predator's perspective. Calif Coop Ocean Fish Invest Rep 34:133-139

Ainley DG, Spear LB, Allen SG, Ribic CA (1996) Temporal and spatial patterns in the diet of the common murre in California waters. Condor 98:691-705

Anderson PJ, Piatt JF (1999) Community reorganization in the Gulf of Alaska following ocean climate regime shift. Mar Ecol Prog Ser 189:117-123

Beamish RJ, Bouillon DR (1993) Pacific salmon production trends in relation to climate. Can J Fish Aquat Sci 50: 1002-1016

Beamish RJ, Noakes DJ, McFarlane GA, Klyashtorin L, Ivanov VV, Kurashov V (1999) The regime concept and natural trends in the production of Pacific salmon. Can J Fish Aquat Sci 56:516-526

Bograd SJ, DiGiacomo PM, Durazo R, Hayward TL and 8 others (2000) The state of the California Current, 1999-2000: forward to a new regime? Calif Coop Ocean Fish Invest Rep 41:26-52

Cairns DK (1987) Seabirds as indicators of marine food supplies. Biol Oceanogr 5:261-271

Clark WG, Hare SR, Parma AM, Sullivan PJ, Trumble RJ (1999) Decadal changes in growth and recruitment of Pacific halibut (Hippoglossus stenolepis). Can J Fish Aquat Sci 56:242-252

Cochrane D, Orcutt GH (1949) Application of least-squares regression to relationships containing autocorrelated error terms. J Am Stat Assoc 44:32-61

Croxall JP, McCann TS, Prince PA, Rothery P (1988) Reproductive performance of seabirds and seals at South Georgia and Signey Island, South Orkney Islands, 1976-1987: implications for Southern Ocean monitoring studies. In: Sahrhage D (ed) Antarctic Ocean and resources variability. Springer-Verlag, Berlin, p 261-285

Davoren GK, Montevecchi WA (2003) Signals from seabirds indicate changing biology of capelin stocks. Mar Ecol Prog Ser 258:253-261

Durazo R, Baumgartner TR, Bograd SJ, Collins CA and 11 others (2001) The state of the California Current, 2000-2001: a third straight La Niña year. Calif Coop Ocean Fish Invest Rep 42:29-60

Francis RC, Hare SR (1994) Decadal-scale regime shifts in the large marine ecosystems of the North-east Pacific: a case for historical science. Fish Oceanogr 3:279-291

Francis RC, Hare SR, Hollowed AB, Wooster WS (1998) Effects of interdecadal climate variability on the oceanic ecosystems of the NE Pacific. Fish Oceanogr 7:1-21

Hatch SA, Sanger GA (1992) Puffins as samplers of juvenile pollock and other forage fish in the Gulf of Alaska. Mar Ecol Prog Ser 80:1-14

Hare SR, Francis RC (1995) Climate change and salmon production in the Northeast Pacific Ocean. In: Beamish RJ (ed) Climate change and Northern fish populations. Can Spec Publ Fish Aquat Sci 121:357-372

Hare SR, Mantua NJ (2000) Empirical evidence for North Pacific regime shifts in 1977 and 1989. Progr Oceanogr 47: 103-146

Hollowed AB, Hare SR, Wooster WS (1998) Pacific basin climate variability and patterns of Northeast Pacific marine fish production. In: Holloway G, Muller P, Henderson D 
(eds) Proceedings of the 10th 'Aha Huliko': a Hawaiian winter workshop on biotic impacts of extratropical climate variability in the Pacific. NOAA NA67RJ0154, SOEST Special Publication, p 89-104

Larson RJ, Lenarz WH, Ralston S (1994) The distribution of pelagic juvenile rockfish of the genus Sebastes in the upwelling region off central California. Calif Coop Ocean Fish Invest Rep 35:175-221

Lenarz WH (1992) Shortbelly rockfish. In: Leet WS, Dewees CM, Haugen CW (eds) California's living marine resources and their utilization. California Sea Grant Ext Publ UCSGEP-92-12, Davis, CA, p 126-127

Lenarz WH, Ventresca DA, Graham WM, Schwing FB, Chavez F (1995) Explorations of El Niño events and associated biological population dynamics off central California. Calif Coop Ocean Fish Invest Rep 36:106-119

Love MS, Yoklavich M, Thorsteinson L (2002) The rockfishes of the Northeast Pacific. University of California Press, Berkeley/Los Angeles, CA

MacGregor JS (1986) Relative abundance of 4 species of Sebastes off California and Baja California. Calif Coop Ocean Fish Invest Rep 27:121-135

Mackas DJ, Goldblatt R, Lewis AG (1998) Interdecadal variation in developmental timing of Neocalanus plumchrus populations at Ocean Station P in the subarctic North Pacific. Can J Fish Aquat Sci 55:1878-1893

Mantua NJ, Hare SR (2002) The Pacific decadal oscillation. J Oceanogr 58:35-44

Mantua NJ, Hare SR, Zhang Y, Wallace JM, Francis RC (1997) A Pacific interdecadal climate oscillation with impacts on salmon production. Bull Am Meteorol Soc 78:1069-1079

McFarlane GA, Beamish RJ (1992) Climatic influence linking copepod production with strong year-classes in sablefish, Anoplopoma fimbria. Can J Fish Aquat Sci 49:743-753

McGowan JA, Cayan DR, Dorman LM (1998) Climate-ocean variability and ecosystem response in the Northeast Pacific. Science 281:210-217

McGowan JA, Bograd SJ, Lynn RJ, Miller AJ (2003) The biological response to the 1977 regime shift in the California Current. Deep-Sea Res Part II 50:2567-2582

Miller AJ, Schneider N (2000) Interdecadal climate regime dynamics in the North Pacific Ocean: theories, observations and ecosystem impacts. Prog Oceanogr 47:355-379

Mills KL, Ralston S, Laidig T, Sydeman WJ (in press) The use of top predator diet as indicators of pelagic juvenile rockfish (Sebastes spp.) abundance in the California Current System. Fish Oceanogr

Montevecchi WA (1993) Birds as indicators of change in marine prey stocks. In: Furness RW, Greenwood JJD (eds) Birds as monitors of environmental change. Chapman \& Hall, London, p 217-266

Montevecchi WA, Myers RA (1996) Dietary changes of seabirds indicate shifts in pelagic food webs. Sarsia 80: $313-322$

Montevecchi WA, Myers RA (1997) Centurial and decadal

Editorial responsibility: Otto Kinne (Editor),

Oldendorf/Luhe, Germany oceanographic influences on changes in northern gannet populations and diets in the north-west Atlantic: implications for climate change. ICES J Mar Sci 54:608-614

Oedecoven CS, Ainley DG, Spear LB (2001) Variable responses of seabirds to change in marine climate: California Current, 1985-1994. Mar Ecol Prog Ser 212:265-281

Peterson WT, Schwing FB (2003) A new climate regime in northeast pacific ecosystems. Geophys Res Lett 30:1-4

Ralston S (1998) The status of federally managed rockfish on the U.S. West Coast. In: Yoklavich M (ed) Marine harvest refugia for west coast rockfish: a workshop. NOAA Technical Memorandum NMFS; NOAA-TM-NMFS-SWFSC255, Pacific Grove, CA, p 6-16

Ralston S, Howard DF (1995) On the development of yearclass strength and cohort variability in 2 northern California rockfishes. Fish Bull 93:710-720

Ralston S, Bence JR, Eldridge MB, Lenarz WH (2003) An approach to estimating rockfish biomass based on larval production, with application to Sebastes jordani. Fish Bull 101:129-146

Schwing FB, Bograd SJ, Collins CA, Gaxiola-Castro G and 15 others (2002) The State of the California Current, 20012002: Will the California Current still keep its cool, or is El Niño looming? Calif Coop Ocean Fish Invest Rep 43:31-68

Sydeman WJ (1999) Climate change and the population biology of common murres and other seabirds of the California Current marine ecosystem. PhD thesis, University of California, Davis, CA

Sydeman WJ, Penniman JF, Pyle P, Ainley DG (1991) Breeding performance in the western gull-effects of parental age, timing of breeding and year in relation to food availability. J Anim Ecol 60:135-149

Sydeman WJ, Hester MM, Thayer JA, Gress F, Martin P, Buffa J (2001) Climate change, reproductive performance and diet composition of marine birds in the southern California Current system. Prog Oceanogr 49:309-329.

Trenberth KE (1990) Recent observed interdecadal climate changes in the northern hemisphere. Bull Am Meteorol Soc 71:988-993

Trenberth KE (1997) The definition of El Niño. Bull Am Meteorol Soc 78:2771-2777

Veit RL, Pyle P, McGowan JA (1996) Ocean warming and long-term change in pelagic bird abundance within the California Current system. Mar Ecol Prog Ser 139:11-18

Venrick EL, McGowan JA, Cayan DR, Hayward TL (1987) Climate and chlorophyll a: long-term trends in the central North Pacific Ocean. Science 238:70-72

Woodbury D, Ralston S (1991) Interannual variation in growth rates and back-calculated birthdate distributions of pelagic juvenile rockfishes (Sebastes spp.) off the central California coast. Fish Bull 89:523-533

Yen PPW, Sydeman WJ, Hyrenbach KD (2004) Marine bird and cetacean associations with bathymetric habitats and shallow-water topographies: implications for trophic transfer and conservation. J Mar Syst 50:79-99

Submitted: October 31, 2003; Accepted: June 29, 2004

Proofs received from author(s): October 7, 2004 